\title{
O novo Conselho Científico Internacional da RPMGF
}

Alberto Pinto Hespanhol,* Rui Nogueira**

A gora que se inicia um Novo Ano, o ano de 2020 e com ele a implementação de diversas atividades previamente discutidas entre os diferentes membros do Corpo Editorial, informamos os sócios da APMGF, bem como os Autores e os Leitores da RPMGF, da criação do Conselho Científico Internacional ("International Board").

Este novo Conselho Científico Internacional inclui Médicos de reconhecido mérito científico e social e tem como objetivo, já tantas vezes referido nos nossos anteriores Editoriais, ${ }^{1-4}$ ser um instrumento que auxilie na estratégia de indexação internacional da revista, à luz do resultado das avaliações da SCOPUS de 2019 e MEDLINE de 2015.

Trata-se de um novo órgão do Corpo Editorial, para além dos já existentes Conselho Editorial, Revisores e Conselho Científico e que tem uma função fundamental na estratégia de projeção internacional da revista.

O Conselho Internacional esta assim em fase final de constituição, e brevemente integrará a estrutura da RPMGF. Agradecemos a todos os que têm aceite o nosso convite para pertencer a este novo Conselho Cientí-

*Editor-Chefe da Revista Portuguesa de Medicina Geral e Familiar. **Diretor da Revista Portuguesa de Medicina Geral e Familiar. fico. Esperamos a sua orientação e apoio nos momentos decisivos da RPMGF, na reflexão das suas grandes temáticas e no aconselhamento das melhores atitudes a tomar em diferentes situações.

A RPMGF fica valorizada com a criação do Conselho Científico Internacional ("International Board") e dá assim mais um passo em frente na sua evolução e crescimento. Este fortalecimento está de acordo com a posição vanguardista MGF em Portugal e do prestígio da APMGF.

\section{REFERÊNCIAS BIBLIOGRÁFICAS}

1. Nogueira, Rui. A partilha do conhecimento num novo ciclo. Revista Portuguesa de Medicina Geral e Familiar, [S.l.], v. 33, n. 3, p. 170, maio 2017.

2. Hespanhol, Alberto Pinto. Contributo de novo modelo editorial da revista para a formação e a investigação em Medicina Geral e Familiar. Revista Portuguesa de Medicina Geral e Familiar, [S.l.], v. 33, n. 4, p. 242, jul. 2017. EDITORIAL

3. Hespanhol, Alberto Pinto. Um ponto de situação do novo modelo editorial da revista. Revista Portuguesa de Medicina Geral e Familiar, [S.l.], v. 33, n. 5, p. 310-2, nov. 2017.

4. Marioto, Tiago et al. O primeiro ano em revisão do novo ciclo da medicina geral e familiar - mudanças e perspetivas. Revista Portuguesa de Medicina Geral e Familiar, [S.l.], v. 34, n. 6, p. 351-352, jan. 2019.

\section{ENDEREÇO PARA CORRESPONDÊNCIA}

E-mail: hespanhol@netcabo.pt https://orcid.org/0000-0002-1212-4487 